JRPIPM. Vol. 3 (2020, no. 2, 61-67)

Jurnal Riset Pendidikan dan Inovasi Pembelajaran Matematika

ISSN: 2581-0480 (electronic)

URL: journal.unesa.ac.id/index.php/jrpipm

\title{
Analisis Kesulitan Siswa SMP dalam Menyelesaikan Soal Materi Teorema Pythagoras
}

\author{
Lila Wulandari ${ }^{1}$, Marchasan Lexbin Elvi Judah Riajanto ${ }^{2}$ \\ ${ }^{1}$ IKIP Siliwangi, Lilawulandari27@gmail.com \\ ${ }^{2}$ IKIP Siliwangi, marchasanlexbin123@gmail.com
}

\begin{abstract}
Difficulties experienced by students in learning greatly affect the achievement of student learning outcomes. This study aims to describe the results of the identification of the types of difficulties and the causes of student difficulties when solving problems based on Polya stages. This type of research is descriptive qualitative with the instrument used in written tests. The subjects of the research were 36 students of class IX at SMP Negeri 9 Cimahi. Based on the analysis that has been done, it can be concluded that the difficulties experienced by junior high school students when completing the Pythagorean theorem questions in the school are 1) difficulty understanding the problem $100 \%$,2) difficulty planning the completion of $40 \%, 3$ ) difficulty implementing the plan $54.4 \%$, and 4) difficulty in re-checking $76.7 \%$. The causes of difficulties include 1) students are not accustomed to writing things that are known and asked of a problem 2) students are not accustomed to drawing conclusions from a mathematical problem 3) Concept errors because students do not understand the concept of the material. So, it is necessary to improve the learning process that prioritizes learning concepts rather than memorizing. Students must be accustomed to solving the application problems of a material. So, students will be able to solve contextual problems related to the material.
\end{abstract}

Keywords: Difficulty Analysis, Pythagorean Theorem

\begin{abstract}
ABSTRAK
Kesulitan-kesulitan yang dialami oleh siswa dalam pembelajaran sangat berdampak pada pencapaian hasil belajar siswa. Penelitian ini bertujuan untuk mendeskripsikan hasil identifikasi jenis-jenis kesulitan dan penyebab kesulitan siswa pada saat menyelesaikan masalah berdasarkan tahapan polya. Jenis penelitian yang dilakukan adalah deskriptif kualitatif dengan instrument yang digunakan tes tertulis. Subjek penelitiannya adalah 36 siswa kelas IX SMP Negeri 9 Cimahi. Berdasarkan analisis yang telah dilakukan dapat disimpulkan bahwa kesulitan yang dialami oleh siswa SMP pada saat menyelesaikan soal teorema Pythagoras di sekolah tersebut adalah 1) kesulitan memahami masalah $100 \%$,2) kesulitan merencanakan penyelesaian $40 \%$, 3) kesulitan melaksanakan rencana $54,4 \%$, dan 4) kesulitan memeriksa kembali 76,7\%. Penyebab kesulitan-kesulitan diantaranya adalah 1) siswa belum terbiasa menuliskan hal-hal yang diketahui dan ditanyakan dari sebuah soal 2) siswa belum terbiasa menarik kesimpulan dari suatu permasalahan matematik 3)
\end{abstract}

Tanggal Masuk: 25 Februari 2020; Revisi: 25 Februari 2020; Diterima: 31 Maret 2020 
Kesalahan konsep dikarenakan siswa belum memahami betul konsep materi tersebut. Sehingga, perlu dilakukan perbaikan proses pembelajaran yang lebih mengedepankan pembelajaran konsep daripada hafalan. Siswa harus dibiasakan menyelesaikan soal-soal aplikasi dari suatu materi. Sehingga, siswa akan mampu menyelesaikan masalah kontekstual yang berkaitan dengan materi tersebut.

Kata Kunci: Analisis Kesulitan, Teorema Pythagoras

\section{Pendahuluan}

Keberlangsungan hidup masa depan adalah masalah pendidikan saat ini. [1] Matematika memiliki peran penting dalam kehidupan, sebab mendasari penemuan dan pengembangan ilmu pengetahuan yang lain. [2] Belum tercapainya tujuan pendidikan dan tercapainya tujuan pembelajaran matematika khususnya akan berkontribusi dalam keberlangsungan hidup Tujuan pembelajaran mengharapkan bahwa siswa mampu mengaplikasikan konsep yang dipelajari untuk memecahkan setiap permasalahan yang ditemukan. Namun pada kenyataanya, siswa kurang tertarik untuk belajar matematika dikarenakan siswa menganggap bahwa matematika terlalu banyak rumus yang harus dihafalkan [3].

Salah satu materi yang dipelajari oleh siswa SMP adalah materi teorema Pythagoras. Materi ini dipelajari di kelas VIII semester genap. Pada materi ini siswa mempelajari mengenai dalil teorema tersebut dan pengaplikasiannya terhadap kehidupan sehari-hari dan konsep-konsep matematika yang lain. Teorema Pythagoras penting untuk dipelajari karena menjadi konsep dasar dalam melakukan perhitungan pada konsep matematika yang lain dan kegunaannya pada penyelesaian masalah kehidupan. Namun pada kenyataannya, siswa masih mengalami kesulitan dalam mengaplikasikan teorema tersebut. Yadrika [4] menyatakan bahwa siswa menganggap materi ini merupakan materi yang sulit. Sehingga, Kesulitan-kesulitan yang dialami oleh siswa pada saat menyelesaikan soal berdampak pada pencapaian hasil belajar yang kurang.

Terkait dengan hal tersebut penulis bermaksud untuk mengalisis kesulitan-kesulitan yang dialami oleh siswa pada saat menyelesaikan soal teorema pythagoras. Kesulitankesulitan siswa dapat dianalisis berdasarkan kesalahan-kesalahan yang dilakukan oleh siswa. Menurut Fitria [5] kesalahan-kesalahan siswa dapat dikategorikan sebagai kesalahan konsep, fakta, prosedur, prinsip dan operasi. Sedangkan menurut Hidayah dalam Yadrika [4] mengkategorikan kesalahan siswa berdasarkan empat tahapan polya yaitu memahami maslah, merencanakan penyelesaian, melakukan penyelesaian sesuai dengan rencana, dan memeriksa kembali hasil yang didapatkan.

Pada penelitian ini, penulis mengadaptasi pendapat hidayah untuk menganalisis kesulitan siswa berdasarkan tahapan polya. Siswa mengalami kesulitan pada saat menyelesaikan soal-soal aplikasi materi teorema pythagoras. Sehingga, soal tersebut menjadi masalah bagi siswa. Diharapkan analisis kesulitan siswa ini dapat menemukan sekaligus mendeskripsikan pada tahapan apa siswa mengalami kesulitan dan ditemukan pula penyebabnya. Oleh karena itu, penulis bermaksud untuk melakukan analisis kesulitan siswa smp dalam menyelesaikan soal materi teorema pythagoras.

\section{Metode Penelitian}

Metode yang digunakan dalam penelitian ini adalah deskriptif kualtitatif. Penelitian ini bertujuan untuk memberikan gambaran secara sistematis, aktual, dan akurat mengenai fenomena yang terjadi dengan pendekatan kualitatif. Subjek dalam penelitian ini adalah kelas IX di SMP Negeri 9 Cimahi tahun pelajaran 2019/2020. Jenis soal yang diberikan 
adalah soal uraian yang berjumlah 5 soal. Soal-soal tersebut mewakili setiap indikator pencapaian kompetensi materi teorema Pythagoras yang terdapat pada kurikulum 2013 revisi tahun 2017. Jawaban tes siswa kemudian di berikan skor yang diadaptasi dari Sumaryanta [6] sebagai berikut :

TABEL 1.Penskoran Tes Tertulis

\begin{tabular}{lc}
\hline \multicolumn{1}{c}{ Aspek Yang Dinilai } & Skor \\
\hline $\begin{array}{l}\text { Siswa menuliskan apa yang diketahui dan ditanyakan pada soal dengan } \\
\text { lengkap dan benar }\end{array}$ & 1 \\
Siswa menuliskan rumus yang digunakan dengan jelas dan benar & 1 \\
Siswa melakukan perhitungan sesuai dengan rumus yang sudah dituliskan & 1 \\
secara terstruktur dan benar & 2 \\
\hline Siswa menuliskan hasil yang relevan dengan jelas & 5 \\
\hline
\end{tabular}

Data hasil penskoran kemudian diolah untuk mengetahui tingkat penguasaan materi dikelas tersebut dengan menggunakan rumus Tingkat Penguasaan (TP) dalam Riajanto [7] :

$$
\mathrm{TP}=\frac{M t}{S M I}
$$

Keterangan :

$\mathrm{Mt}=$ Rata-rata skor total yang diperoleh siswa

SMI = Skor Maksimal Ideal

TABEL 2.Kriteria Tingkat Penguasaan (TP)

\begin{tabular}{cc}
\hline TP & Kategori \\
\hline $0,80 \leq \mathrm{TP} \leq 1$ & Sangat Tinggi \\
$0,65 \leq \mathrm{TP} \leq 0,80$ & Tinggi \\
$0,50 \leq \mathrm{TP} \leq 0,65$ & Cukup \\
$0,30 \leq \mathrm{TP} \leq 0,50$ & Rendah \\
$0 \leq \mathrm{TP} \leq 0,30$ & Sangat Rendah \\
\hline
\end{tabular}

Hasil uraian jawaban siswa kemudian dianalisis untuk mengetahui jenis kesulitan yang dialami oleh siswa. Adapun indikator-indikator kesulitan yang digunakan dalam penelitian ini sebagai berikut :

TABEL 3. Jenis-jenis kesulitan beserta indikatornya berdasarkan tahapan polya

\begin{tabular}{ll}
\hline \multicolumn{1}{c}{ Jenis Kesulitan } & \multicolumn{1}{c}{ Indikator Kesulitan } \\
\hline Memahami masalah & Kesulitan dalam menuliskan diketahui dan ditanyakan \\
Merencanakan penyelesaian & $\begin{array}{l}\text { Kesulitan siswa dalam menuliskan rumus atau } \\
\text { menggambarkan model matematika }\end{array}$ \\
$\begin{array}{l}\text { Melaksanakan rencana } \\
\text { penyelesaian }\end{array}$ & Kesulitan melakukan perhitungan \\
Memeriksa kembali & Kesulitan dalam menuliskan hasil atau simpulan \\
\hline
\end{tabular}

\section{Hasil dan Pembahasan}




\subsection{Hasil}

Berdasarkan hasil tes yang dilaksanakan terlebih dulu dicari pencapaian penguasaan siswa terhadap materi. Untuk memberikan gambaran pencapaian siswa pada tes tersebut, berikut tabel hasil tingkat penguasaan(TP) siswa :

TABEL 4. Hasil Interpretasi Tingkat Penguasaan (TP)

\begin{tabular}{ccc}
\hline Rata-Rata Skor & SMI & TP \\
\hline 10,125 & 25 & 0,405 \\
\hline
\end{tabular}

Setelah mengetahui tingkat penguasaan matematik siswa, lalu dilakukan analisis terhadap jenis kesulitan-kesulitan yang dialami oleh siswa. Jenis-jenis kesulitan tersebut disajikan dalam tabel berikut :

TABEL 5. Persentase kesulitan pada setiap soal

\begin{tabular}{lccccc}
\hline \multicolumn{1}{c}{ Jenis Kesulitan } & Soal 1 & Soal 2 & Soal 3 & Soal 4 & Soal 5 \\
\hline $\begin{array}{l}\text { Memahami masalah } \\
\begin{array}{l}\text { Merencanakan } \\
\text { penyelesaian }\end{array}\end{array}$ & $100 \%$ & $100 \%$ & $100 \%$ & $100 \%$ & $100 \%$ \\
$\begin{array}{l}\text { Melaksanakan rencana } \\
\text { penyelesaian }\end{array}$ & $22.2 \%$ & $2.8 \%$ & $72.2 \%$ & $66.7 \%$ & $36.1 \%$ \\
Memeriksa kembali & $75 \%$ & $0 \%$ & $52.8 \%$ & $61.1 \%$ & $94.4 \%$ \\
\hline
\end{tabular}

Berikut ini tabel rata-rata kesulitan yang dialami oleh siswa :

TABEL 6. Persentase rata-rata kesulitan siswa

\begin{tabular}{lc}
\hline \multicolumn{1}{c}{ Jenis Kesulitan } & Persentase \\
\hline Memahami masalah & $100 \%$ \\
Merencanakan penyelesaian & $40 \%$ \\
Melaksanakan rencana penyelesaian & $54.4 \%$ \\
Memeriksa kembali & $76.7 \%$ \\
\hline
\end{tabular}

\subsection{Pembahasan}

Dari tabel 4 dapat dilihat bahwa hasil tes menunjukan tingkat penguasaan siswa terhadap materi berada pada kategori rendah. Hasibuan [8] menyatakan penguasaan materi siswa yang rendah bisa diakibatkan oleh rendahnya pemahaman konsep siswa dan kesulitan menganalisa soal yang akhirnya siswa mengalami kesulitan-kesulitan pada saat pengerjaan. Untuk mengetahui hal tersebut maka dilakukan analisis jenis-jenis kesulitan yang dilakukan oleh siswa yang disajikan pada tabel 5 .

Pada seluruh soal siswa mengalami keulitan pada kategori memahami masalah yaitu siswa tidak menuliskan apa yang diketahui dan ditanyakan dari soal. Siswa mampu menyelesaikan soal namun belum terbiasa menuliskan hal tersebut. Padahal, dengan menuliskan diketahui dan ditanyakan akan membantu siswa dalam menentukan arah penyelesaian. Kemudian, kesulitan kedua yang paling banyak dilakukan oleh siswa adalah kategori memeriksa kembali. Siswa mampu menuliskan hasil angka yang diperoleh namun, terlihat kesulitan dalam menyimpulkan suatu permasalahan. Berikut contoh jawaban siswa : 


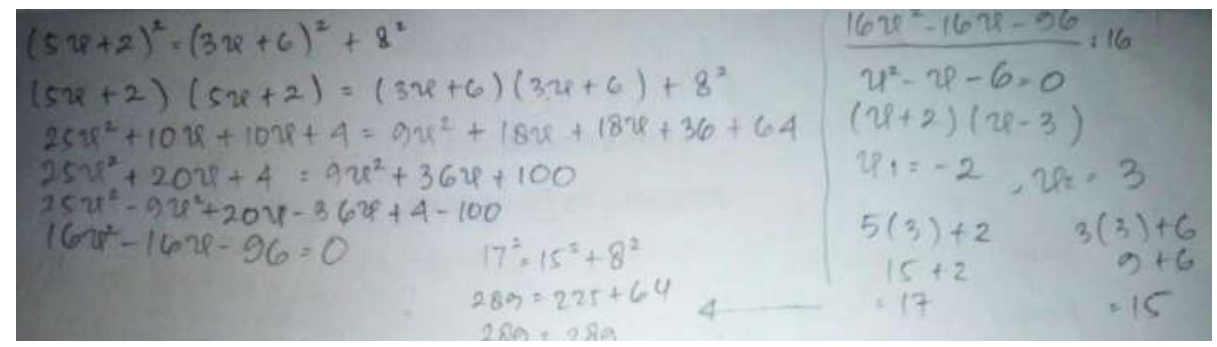

Gambar 1. Jawaban Siswa

Jawaban siswa diatas, merupakan jawaban terhadap soal 1 yang meminta siswa untuk memeriksa apakah teorema Pythagoras berlaku pada sebuah segitiga. Siswa tidak menuliskan hal-hal yang diketahui dan ditanyakan dari soal. Ia melakukan perhitungan dengan benar namun, tidak membuat kesimpulan atas hasil hitung yang didapatkan. Kemampuan siswa dalam membahasakan hasil yang diperoleh terlihat masih kurang. Padahal, konsep yang digunakan sudah benar dan konsep prasayarat yaitu aljabar sudah mampu siswa terapkan. Siswa yang memiliki kemampuan menulis matematik yang baik maka juga akan mampu menyelesaikan soal-soal yang sifatnya bukan hanya meminta hasil hitung namun juga soal-soal yang meminta untuk menarik kesimpulan. Dalam hal ini, siswa perlu dilatih dengan soal-soal yang juga membiasakan siswa bukan hanya untuk menghitung namun juga menarik kesimpulan dari suatu permasalahan dan dikomunikasikan dengan bahasa sendiri.

Kemudian, siswa juga mengalami kesulitan pada saat melaksankan rencana yaitu kesulitan dalam operasi hitung. Kesulitan operasi dialami oleh siswa paling banyak pada soal no 5. Soal tersebut merupakan soal aplikasi teorema Pythagoras yang dikoneksikan dengan konsep materi kecepatan. Siswa diminta untuk menentukan selisih waktu yang dibutuhkan dengan dua jarak yang berbeda. Salahsatu jarak akan ditemukan oleh siswa dengan menggunakan teorema Pythagoras. Berikut contoh jawaban salahsatu siswa pada soal tersebut :

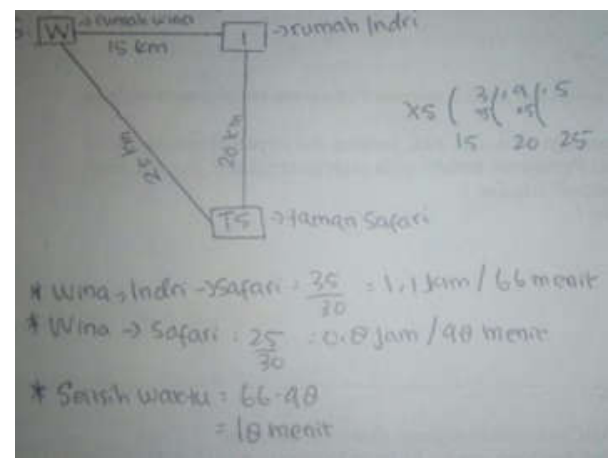

Gambar 2. Jawaban Siswa

Siswa mampu menerapkan teorema Pythagoras dan menghubungkannya dengan konsep kecepatan, jarak, dan waktu. Namun, pada saat tahapan perhitungan siswa mengalami kesulitan dalam menghitung. Kesulitan hitung dilakukan siswa pada saat mencari waktu yang diperlukan oleh Wina jika menjemput Indri terlebih dahulu yaitu 35 dibagi 30 hasilnya adalah 1,1 yang harusnya adalah 1,17 dimana jika dibulatkan menjadi 1,2. Kesulitan hitung ini diakibatkan oleh kurangnya pemahaman siswa terhadap konsep pembulatan bilangan pecahan desimal. Kesulitan pada saat melakukan perhitungan ini menyebabkan kesalahan pada saat menuliskan hasil. Penyelesaian soal-soal aplikasi 
memerlukan ketelitian yang lebih dari penyelesaian soal-soal rutin. Dikarenakan, siswa harus mengerahkan segala kemampuan dan pengalaman belajar yang pernah dialami untuk menyelesaikannya.

Kesulitan selanjutnya yang dialami oleh siswa adalah kesulitan menentukan rencana penyelesaian. Berikut contoh jawaban salahsatu siswa pada soal no 4 :

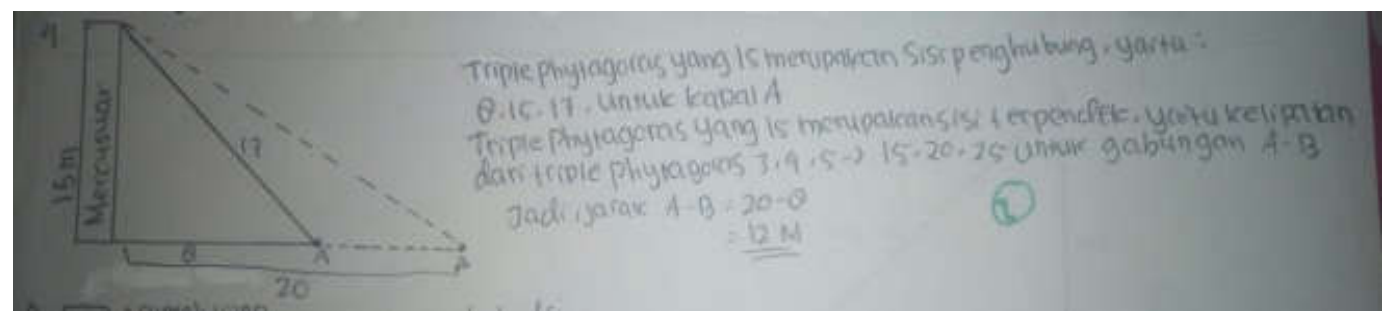

Gambar 3. Jawaban Siswa

Soal 4 merupakan soal aplikasi materi perbandingan sisi segitiga siku-siku istimewa dengan sudut $45^{\circ}, 30^{\circ}$, dan $60^{\circ}$. Pada saat menentukan rencana penyelesaian yaitu memodelkan permasalahan tersebut siswa mengalami kesulitan. Gambar siswa hampir benar namun tidak dicantumkan sudut-sudutnya. Siswa melakukan perhitungan dengan menggunakan triple pytagoras namun, ada kekeliruan konsep. Segitiga siku-siku dengan ukuran sudut istimewa memiliki perbandingan sisi yang khusus. Sehingga, tidak semua triple Pythagoras berlaku pada segitiga tersebut. Kesalahan konsep ini menyebabkan kesalahan jawaban yang didapatkan.

Yadrika [4] dalam penelitiannya menyatakan bahwa kesalahan konsep paling banyak dilakukan oleh siswa pada saat menyelesaikan soal teorema pythagoras. Siswa menganggap bahwa ada ataupun tidak sudut istimewa pada segitiga tersebut tidak berpengaruh pada ukuran segitiga.

Kesalahan konsep ini dialami oleh siswa dikarenakan kurangnya pemahaman materi oleh siswa dan kurang bermaknanya pembelajaran. Rohmah dan Sutiarjo [9] menyatakan kurangnya pemahaman konsep siswa disebabkan karena pada saat pembelajaran siswa berpikir secara tidak lengkap. Proses pembelajaran yang kurang bermakna bagi siswa, bisa jadi disebabkan oleh karena siswa belum memahami betul materi yang diajarkan. Hendriana dan Fitriani [10] mengemukakan bahwa siswa akan menghubungkan pengalaman pembelajaran yang bermakna untuk pengalaman yang baru. Sehingga jika siswa menganggap suatu pembelajaran bermakna maka ketika menemukan permasalahan yang berkaitan dengan apa yang dipelajari, siswa mudah untuk menghubungkannya.

\section{Kesimpulan}

Berdasarkan analisis yang telah dilakukan dapat disimpulkan bahwa kesulitankesulitan yang dialami oleh siswa SMP pada saat menyelesaikan soal teorema Pythagoras di sekolah tersebut adalah 1) kesulitan memahami masalah 100\%, 2) Kesulitan merencanakan penyelesaian 40\%,3) kesulitan melaksanakan rencana 54,4\%, dan 4) kesulitan memeriksa kembali 76,7\%. Penyebab kesulitan-kesulitan diantaranya adalah 1) siswa belum terbiasa menuliskan hal-hal yang diketahui dan ditanyakan 2) siswa belum terbiasa menarik kesimpulan dari suatu permasalahan matematik 3) Kesalahan konsep dikarenakan siswa belum memahami betul konsep materi tersebut. Sehingga, siswa belum mampu menyelesaikan soal dengan baik. Kurangnya pemahaman siswa bisa diakibatkan oleh pembelajaran yang belum menitikberatkan pada pembelajaran konsep. Untuk meminimalisir kesulitan-kesulitan tersebut, perlu dilakukan perbaikan proses 
pembelajaran. Siswa harus diarahkan kepada pembelajaran konsep dan dibiasakan menyelesaikan soal-soal aplikasi dari suatu materi. Siswa yang tidak hanya hafal rumus namun memahami konsepnya, akan mudah menyelesaikan masalah-masalah yang berkaitan dengan materi tersebut di kehidupan sehari-harinya. Selain itu, siswa juga harus dibiasakan untuk membahasakan kalimat matematik kebahasanya sendiri dengan melatih siswa mengerjakan soal-soal yang membutuhkan penarikan kesimpulan.

\section{Daftar Pustaka}

[1] E. Suherman, Turmudi, D. Suryadi, T. Herman, Suhendra, S. Prabwanto, Strategi Pembelajaran Matematika Kontemporer. Bandung: Universitas Pendidikan Indonesia, 2003.

[2] M. L. Riajanto, Pengembangan Pembelajaran Era Post Modern Menuju Ketercapaian Kemampuan Matematis Siswa. Jurnal Ilmiah Program Studi Matematika STKIP Siliwangi Bandung, 81, 2014.

[3] A. Yusuf, dan N. Fitriani, "Analisis Kesalahan Siswa Smp Dalam Menyelesaikan Soal Persamaan Linear Dua Variabel Di Smpn 1 Campaka Mulya-Cianjur". JPMI (Jurnal Pembelajaran Matematika Inovatif) vol. 3, no. 1 (2020): 59-68.

[4] G. Yadrika, S. Amelia, Y. Roza, dan Maemunah, "Analisis Kesalahan Siswa SMP dalam Menyelesaikan Soal pada Materi Teorema Pythagoras dan Lingkaran". JPPM (Jurnal Penelitian dan Pembelajaran Matematika) vol. 12, no. 2 (2019): 195-212.

[5] T. N. Fitria, "Analisis Kesalahan siswa dalam menyelesaikan soal cerita berbahsa inggris pada materi persamaan dan pertidaksamaan linear satu variabel", MATHEdunesa 2, no. 1 (2013)

[6] Sumaryanta, "Pedoman Penskoran", Indonesian Digital Journal of Mathematics and Education, vol. 2, no. 3, 2015, 181-90.

[7] M. L. Riajanto, Peningkatan Kemampuan Pemahaman Geometris Siswa Smp Melalui Pendekatan Matematika Realistik Berbantuan Software Geometer's Sketchpad. Bandung : Universitas Pendidikan Indonesia, 2014

[8] I. Hasibuan, "Hasil Belajar Siswa Pada Materi Bentuk Aljabar Di Kelas Viism Negeri 1 Banda Aceh Tahun Pelajaran 2013/2014". Jurnal Peluang vol. 4, no. 1 ,2015,10-11.

[9] M. Rohmah, dan S. Sutiarso, "Analysis Problem Solving in Mathematical Using Theory Newman", EURASIA Journal of Mathematics, Science and Technology Education, vol. 14, no. 2, 2018, 671-681.

[10] H. Hendriana, dan N. Fitriani, "Mathematical Abstraction Of Year 9 Students Using Realistic Mathematics Education Based On The Van Hiele Levels Of Geometry". Jurnal Didaktik Matematika, vol. 6, no. 1, 2019, 1-11.. 